\title{
18
}

\section{Niu Mana, Sport, Media and the Australian Diaspora}

\author{
Katerina Martina Teaiwa
}

\section{Katerina Teaiwa: Personal Journey}

I grew up on the Laucala campus of the University of the South Pacific (USP) as my mother, Joan Teaiwa, worked there as a course developer in extension services from 1980 to 2000, and my elder sister, Teresia Teaiwa, as a lecturer in history/politics from 1994 to 2000. We took music lessons on campus from the wonderful Mr Ueta Solomona, played tennis at the USP courts, swam regularly at the USP pool, did exercise classes at the USP gym and I played on the White Fire basketball team led by USP Professor Randy Thaman and Bob Tuxon.

My mother had started a ballet school in Suva in the 1980s and my sisters and I were avid dancers. In the mid-1990s, Professor Epeli Hau'ofa was expanding the Oceania Centre for Arts and Culture and looking for artists and performers to develop their work at the centre. He introduced me to the very talented Allan Alo and together we founded the Oceania Dance Theatre (ODT) with Letava Tafuna'i. I danced for years with Allan in various shows including USP's early dance theatre productions, collaborating with musicians and visual artists. ODT travelled to Honolulu where I had completed my MA in Pacific Islands Studies and to Canberra where I was doing my PhD at The Australian National University (ANU). I discovered that the anthropology department had been recycling name tags on the doors for years and Epeli's name was still there from the 1970s on the back of a label being used in the late 1990s. 
It is amazing to see where the ODT dancers are today after Allan's and Peter Espiritu's guidance and mentorship. I am now an associate professor at ANU. I serve on the advisory board for the Oceania Centre for Arts, Culture and Pacific Studies and have continued to collaborate with staff and artists over the years. Pacific studies was greatly influenced by Epeli, Allan and Teresia, who have sadly all passed away, leaving tremendous legacies in the arts and scholarship at USP and across the region.

Teaiwa, K.M. 2016. Niu Mana, Sport, Media and the Australian Diaspora. In M. Tomlinson and Ty P. Kāwika Tengan (eds), New Mana: Transformations of a Classic Concept in Pacific Languages and Cultures. Canberra: ANU Press, 107-30.

Republished with the kind permission of ANU Press.

\section{Prelude}

In the trailer for In Football We Trust, a documentary directed by Tony Vainuku and produced by Erika Cohn of Idle Wild films, several young Polynesian men identify themselves as playing high school football. An inter title appears stating that approximately 150,000 Samoans and Tongans now live in the United States and are 56 times more likely to make it into the National Football League (NFL) than any other 'race' despite one in four of the same group living in poverty. And why is their success rate so high? Words like faith, talent, culture, warrior and family flash across the screen, followed by 'it's the only option' (IFWT Productions and ITVS 2014).

Former running back Vai Sikahema appears, stating that it is unfair for kids growing up to be told they will make it into the NFL. But then a series of players and a mother make it clear that football is seen as a 'door', a pathway to major success, not just for the individual but for the whole family. A young man says that all his mother's brothers are in prison, and all his father's brothers are in prison as well. The soundtrack for the trailer is a bombastic chorus that increases in tempo as the final words proclaim the film title encapsulating a spirit of American patriotism, faith, even blind faith, and also a worrying edge. What if you don't make it? Or what if you do make it and life just gets more challenging? The suicide of Samoan All-Pro NFL player Junior Seau by gunshot in 2012 hangs like a spectre over this trailer. His autopsy showed he had suffered from 
numerous head injuries. He left no suicide note but a page was found handwritten with the lyrics of his favourite country song 'Who I Ain't'. Co-written by his friend, Jamie Paulin, it describes a man who regrets the person he has become (Steeg 2012).

\section{Introduction}

In this chapter I present some preliminary thoughts on 'new mana' and a discussion of how globalisation and the Pacific diaspora might compel us to reimagine key Pan-Pacific concepts such as mana, tapu, talanoa, va, Moana, Oceania and Solwara (salt water) in new or, to use 350Pacific.org's play on words, niu ways. ${ }^{1}$ By 'key' I don't mean that these words are the same or even exist in every Pacific language, but rather that a sense of spiritual efficacy, agency and authority or power; sacred or taboo things, people and places; relational space; the ocean as material, pragmatic, connective and sacred; and the Pacific as a region shaped by shared kinship, are important across most contemporary Pacific cultures and contexts. Some call this the 'Pacific Way' (Crocombe 1976), an idea still relevant in spite of the critiques of Pacific political scientists over the years (Lawson 2010).

In spite of many scholarly assumptions about the differences between Melanesians, Micronesians and Polynesians, the concepts I have mentioned are relevant across communities who care about what they see as destructive global forces affecting the lives of people in the diaspora, in small islands, and in the highlands of the Pacific's largest islands. This is seen vividly in 350Pacific.org's climate change protests across the region and in the Madang Wansolwara Dance gathering in August 2014 of artists, activists, scholars, civil society and church leaders in Papua New Guinea, for example. ${ }^{2}$ These concepts are thus transformed, reimagined and applied according to historical, political, environmental and economic contexts, and increasingly drive regional activism. At the heart of it is, as scholars

\footnotetext{
1 Niu is a common word for coconut across many Pacific languages. In Mallon and Pereira's work (see Mallon and Pereira 2002), and in popular parlance in Aotearoa New Zealand, niu converts any negative connotations of the word coconut, signalling race or ethnicity negatively or implying an islander is non-modern or 'fresh off the boat', into a positive term marking Pacific flavours or styles that have infused New Zealand national identities.

2 350Pacific.org is a global climate movement for promoting grassroots climate change activism and information. 350Pacific.org is represented by the 'Pacific Climate Warriors' in various actions and events. See more at 350Pacific.org.
} 
such as Margaret Jolly have argued, an enduring sense of collective and relational personhood shaped by both indigenous heritage and Christian values and concepts (Jolly interviewed by Giggacher 2014).

While many have explored mana in either specific cultural and linguistic contexts such as Hawaiian, Fijian, Māori, Tongan and Samoan, and in what I would call new age gaming (Golub and Peterson 2016) and intense spiritual remix mode (Morgain 2016), I would like to consider mana through an interdisciplinary Pacific Studies lens, and in diverse Pan-Pacific (intercultural or regional), Pasifika, diasporic and postcolonial contexts. While it is beyond the scope of my discussion here on diaspora and sport, I also have questions about how far we can take a discussion of mana and commerce or industry, mana and the commodity sign, and mana in the context of indigenous traditions, such as fa' Samoa, or anga fakatonga, and sexuality, given the often conservative, Christian, heteronormative and ethno-nationalist values within Pacific communities. Mana is about both limits and possibilities, applications and denials within a system of specific contemporary Pacific values and ideas.

\section{The Australian Context}

The topic of mana and sport is not something I sought out for research but rather something that developed as I created the undergraduate teaching program in Pacific Studies at The Australian National University (ANU) over the past seven years. We currently run the only Pacific studies teaching program at any level in Australian higher education and there is very little visibility for the field as a potential area of study in the primary or secondary school system (Rose et al. 2009). As I was trying to imagine how to expand the program and attract students, I was forced to think more broadly about how the Pacific featured in the national Australian consciousness (Teaiwa 2007). Several things became clear very quickly.

Aside from the obvious and dominant pragmatic and policy contexttied primarily to Australia's regional aid, development and governance agenda-there is very little content on the Pacific in the school system in any Australian state. And while there is a wealth of writing about the Pacific Islands, very little of it is available as teaching material and most of it does not engage the Pacific diaspora (Rose et al. 2009). There are just a handful of scholars who do research on Pacific communities in Australia, including research on South Sea Islanders, the descendants of Melanesians 
and other Pacific Islanders forced to work on Australian sugar plantations (see, for example, Banivanua-Mar 2007; Boucher 2012; Lee and Francis 2009; Rose et al. 2009; Vasta 2004). Thus, in Pacific studies in Australia, which is geographically in Oceania and where there is significant Pacific research and policy work, there is a preference for engaging the Pacific out there in the Islands, not the Pacific within Australian cities and neighbourhoods. And neither the domestic nor the island context are seen as relevant for Australian education (Rose et al. 2009; Teaiwa 2007).

Furthermore, compared with New Zealand, and increasingly the United States, Pacific Islanders are not a recognised equity category or community. Statistics on the exact numbers of Islanders in Australia are not readily available, although a reasonable estimate based on census reports for ancestry, including Māori and Indo-Fijians, would put the total around 2 per cent or 400,000 , which would be half a percentage less than the estimated Indigenous Australian population (see Pryke 2014; Pryor 2013; Queensland Health 2013). Pacific communities are primarily resident in New South Wales (NSW) and Queensland and are growing in Victoria, the Australian Capital Territory (ACT), South Australia, Western Australia and the Northern Territory.

Despite Australias long history of engagement with the south-west Pacific, particularly Papua New Guinea, and with Nauru and Kiribati, most 21st-century Pacific migrants are not Melanesian or Micronesian but Polynesian (Pryke 2014). The majority of migrants do not come straight from the Islands, but take advantage of the Trans-Tasman Agreement and move from New Zealand to Australia, drawn by the possibilities of employment within the strong Australian economy. This is certainly the case for the large Māori Australian population, sometimes referred to as 'Mozzies' in the media (Pryor 2013). Many trans-Tasman migrants regularly identify as New Zealander, and many Māori, duplicating structural relations with Pacific migrants back in New Zealand, prefer to be counted or imagined separately from Pacific Islanders (see Teaiwa and Mallon 2005). These factors make it difficult to get a sense of the real Pacific population size in Australia.

Because I expected that future students in Pacific studies would include Pacific Islanders of the diaspora, I sought as much information as possible about Pacific communities in Australia and soon realised there were two dominant and highly visible arenas for positive Pacific participation in the Australian social and cultural landscape: sport and popular 
culture. Within these arenas, it is the Pacific Islander male, and more specifically Polynesian male, who is the most visible (Lakisa et al. 2014). The Melanesian diaspora by contrast is almost invisible despite the fact that there are increasing numbers of mixed heritage Papua New Guinean (PNG) Australians who often come from families with PNG mothers and Australian fathers because it is still difficult to migrate from Melanesia to Australia, compared with, for example, central and eastern Polynesia to New Zealand (see Lewis-Harris 2011; Pryke 2014).

There is a corresponding arena of negative visibility for Pacific communities, again dominated by Polynesian males, within the criminal justice system at all levels. For example, in 2008 the community liaison officer at the Woodford correctional facility in Queensland, a maximum security prison, told me that 10 per cent of their population consists of young Pacific males. And stories on Pacific Islander gangs and crime abound in Australian and New Zealand newspapers, television and online platforms (see, for example, Ansley 2012; Betz 2013; Hill 2013). The Woodford officer, however, also stressed that the Pacific population was the most organised and positive, fostering links with other inmates, especially Indigenous Australians, and creating cultural programs to connect with their families (personal communication, November 2008).

In a context where Pacific communities migrate to Australia for strong economic reasons, and where their visibility is often shaped by negative representations in the media, the corresponding 'positive' arenas of sport and popular culture become even more important as spaces in which Pacific people can counter negative stereotypes with narratives of cultural pride, agency and citizenship (Lakisa et al. 2014; Uperesa 2014). Such positive participation and citizenship is captured by the notion of communal mana. Brendan Hokowhitu usefully frames this convergence of mana and sport in the New Zealand context in terms of a history of colonialism, sport and European settlement:

For a culture on the brink of extinction and subjected to explicit racism in nearly all walks of society, sport offered täne a sort of salvation. Furthermore, given the national hysteria for rugby throughout the twentieth century and the consequent status of the game, it is not surprising that, for Māori men, the rugby and rugby league field was a site where they could gain their community's respect and thus mana. One need only look at the obituaries in Mana Magazine to recognize that tāne are eulogized for their sporting feat (Hokowhitu 2004:269-70). 
Vince Diaz, in his discussion of American gridiron or football, similarly describes this phenomenon as 'beating the colonizer at his own game' (Diaz 2011:97). While he acknowledges the positive potential of sport, Hokowhitu is critical of dominant, hypermasculine representations of what he calls the 'naturally physical' Māori man epitomised by sports such as rugby and American football circulated by mass media, and he challenges Māori men to live beyond these dominant constructs (Hokowhitu 2004:266, 278).

While Hokowhitu was not describing a Māori diasporic context, I became interested in the idea of gaining mana through sport both in the islands and overseas and the differences between those contexts. The word mana has become quite common with a taken-for-granted meaning in English as a kind of spiritual power or potency that can manifest in persons, objects, places or acts. Mei Winitana, who does write about the Māori diaspora, describes the mana in 'Mana Wahine Māori' in Australia, with reference to the works of Maori Marsden in the 1970s and Paul Tapsell in the 1990s:

Mana can be likened to the Greek equivalent of 'dunamai', indicating a 'capability' towards power ... This capability may be described as charisma, an indefinable ' $\mathrm{X}$ factor' that some people possess that influences and inspires others. Charismatic people are telegenic, that is, they project a certain look, particular warmth in their smile, and a personal aura or presence. They communicate in ways that touch the minds and hearts of people for both positive and negative purposes (Winitana 2008:2).

Media influence can enhance this telegenic quality, promoting both a provocative and reactive image for public consumption (ibid.:2). The prominence of sport and popular culture across all forms of media, and the rise in Pacific Islander and Màori participation within these fields, coupled with the expectations of family and community (Besnier 2012; Uperesa 2014), dramatically increase the pressures on athletes and popular artists to be responsible for not just their own, but everyone's image, everyone's hopes and everyone's mana. The expectations can be unbearable and coupled with other factors including injury or loss of contract, the suicide or attempted suicide rates of rugby league players are growing at a worrying rate, similar to their football counterparts (Cadzow 2013; Massoud 2013). 
The backlash from Tongan and other Pacific communities in Australia and the United States towards Australian comedian Chris Lilley's ABC and HBO-syndicated show Jonah from Tonga (Lilley 2014), underscores this widespread aversion to negative public representation. In reaction to Lilley, in controversial brownface and playing a young, misunderstood, delinquent Tongan teenage male with a propensity for swearing, scholars and church leaders protested, and young people mounted the countercampaign \#MyNameisNOTJonah across Twitter and Facebook. Leitu Havea's selfie, circulated widely on social and regular media, proclaimed:

I am a proud Tongan

I've NEVER spent time in prison

I was NEVER suspended from school

I am currently studying for my university degree

\#MyNameisNOTJonah

\#ChangeStartsHERE \#ProudPoly

(SBS 2014).

\section{Theorising Mana}

In his article 'Rethinking Mana', Roger M. Keesing (1984) critiques the predominant notion-a notion based on Robert Henry Codrington's work, which he says came to dominate anthropological writing - of mana as a spiritual essence or power that could be gained or lost (compare with Kolshus 2016). He re-examined mana by taking a comparative linguistic perspective, arguing that it is not classically a noun but rather a stative verb. Things and human enterprises are mana rather than have mana. He argued that we can speak of the mana-ness of a thing or act, and things that are mana are efficacious, potent, successful, true, fulfilled and realised. In short, they 'work' (ibid.:138). So, for example: a stone used magically that actually works, a fisherman's abundant catch, and a potion that heals, all are mana. In all contexts, ancestors, spirits and the gods help make people and things mana. But the notion of mana as a noun denoting substantive power is, as many have observed, prominent in and beyond Polynesia and it is this definition of mana that has come to dominate our application of the term.

In 'Retheorizing Mana', Matt Tomlinson (2006) points out that Keesing did not include Christian visions of Oceanic mana and that Christianity might be the key to rethinking mana in the contemporary Pacific. $\mathrm{He}$ argues that mana became a standard noun not just in English- 
language anthropological literature but in Fijian and as used by Fijians too. The concept underwent transformation in the process of the missionary transcription of Pacific languages, and particularly in the translation of the Bible. It is now typically used as a noun, associated not only with ancestors and chiefs but also with church leaders (see also Tomlinson and Bigitibau 2016).

Tomlinson argues that Christian transformations of mana 'were not simply grammatical, nor simply a matter of substantivizing mana ... The transformations of mana were metonymic of wider political processes' (2006:180). For example, the creation of a permanent elite chiefly class in Fiji via British colonial policy reified custom and as such this class was rationalised accordingly - they, the chiefs, must have mana. He further argues that by the same token, mana can slip away or be lost: he quotes Christina Toren's observation that 'a chief's mana is not what it was ... because they are all Christians, and so the power of the ancestor gods has diminished' (Tomlinson 2006:180). One particular area where this is observed is in effective speech: only God can speak with automatic effectiveness, not chiefs.

On a relevant point for my argument about masculinity and sport, Tomlinson also argues that for Fijians, when configuring mana negatively, there is seen to be a loss in male physical strength and prowess compared with the past. And while he does not mention it explicitly, I imagine this has something to do with the transformation of the warrior class into the modern institutions of sport, military and police. So Fijian mana today is often configured negatively, in terms of its disappearance, but it is clear that male sporting heroes and soldiers are viewed to an extent, in Ty P. Kāwika Tengan and Jesse Markham’s (2009) terms, as contemporary warriors signalling a pre-colonial masculinity.

Diaz takes this point further, echoing the sentiments of the documentary In Football We Trust by stating:

The key Polynesian concept that best captures ... what is at stake in Samoan and other Polynesian performances on the American gridiron is mana. Mana is what accounts for this remarkable and unrivalled success as an ethnic or even demographic group-no other racial or ethnic group and no other similarly-sized community in the world has ever produced the number of major college and professional football players per capita. In the simplest terms possible to understand in English, mana is a powerful presence or force to be found in people, animals, and even inanimate 
objects, and as might be imagined in post-missionary Christianity, mana also gets ultimately linked with God, and service and obligation to God ... Precisely when it is hitched to warrior traditions in powerful ways, American football can be viewed as a virtual stage for the performance of Samoan manhood and masculinity and the broader values in fa'a Samoa through mana (Diaz 2011:101).

The stakes of the mana of elite players in the context of the broader community are well illustrated by Diaz's analysis of gay NFL star Esera Tuaolo's public coming out on national TV (after his retirement), which resulted in a tsunami of criticism and abuse from his Samoan community. People were happy when his football enhanced their perceived collective mana but when he publicly announced his sexuality, the response from one blogger was:

Talofa Esera, You are a disgust and menace to Samoan culture! I guess you're out of your mind! God hates gays as stated in the bible. What is wrong with you? Do not associate God with these filthy faggots and maggots. Tell your parents that you are gay and see what their reactions might be (Diaz 2011: 97).

Setting aside my own personal judgement about such nasty comments, my question is: what happens when we add sport, the diaspora and mass media to this discussion of mana? The hysteria comes partly from the social significance and great visibility of sport and, like popular culture, its potential to uplift as well as demonise entire communities while simultaneously exposing certain values, or revealing a diversity of values, including homophobia. If mana is potency, whether individual or collective, physical or spiritual, then the immense presence of sport and media in countries where Pacific diasporic groups are most prominent means that social values - uplifting ones like strength and courage, and degrading ones like homophobia and intolerance-will necessarily be pulled into any discussion of mana.

Success in sports helps reinstate a male efficacy perceived to be lost through colonialism, migration, minority status in the diaspora, and class status (Uperesa 2014). Tengan and Markham discuss similar issues, stating that football:

becomes a site for the practice and fulfilment of family and spiritual values of faith and loyalty, especially for islanders in the diaspora. At the same time, the Polynesian male warrior becomes a commodity image to be sold for big business (2009:2414). 
Sport is marketed as a hypermasculine spectacle for society as a whole. Furthermore, they discuss how the black super-athlete reinforces racial hierarchies and both glorifies and demonises primitive hypermasculinity. They argue, 'Within the present configuration of the sports-media complex, islander men, like African American and Native American men, have become commodified and consumed as racialized and hypermasculine spectacle' (Tengan and Markham 2009:2414; see also Lakisa et al. 2014). There is a complex relationship between the commodified spectacle and notions of leadership, status or authority and the interpretation and significance of sport, popular culture and political icons for Pacific audiences. Within all this are both internally generated and externally integrated biases, racism, sexism, homophobia and notions of class.

In the Australian diaspora, participation in sport and popular culture is a particular area of visibility and success for Pacific peoples that holds great meaning for minority communities (Lakisa et al. 2014; Uperesa 2014). And this is key for Australia because the spheres of politics and higher education are not currently arenas in which Islanders are visible compared with New Zealand and the United States where there are politicians and PhDs of Pacific descent who are nationally celebrated. Sport is not just an athletic opportunity but an economic one that allows successful players class mobility, and to fulfil cultural obligations, what Fa'anofo Lisaclaire Uperesa describes as 'the opportunity to give back ... [and the] privilege of performing tautua (service, in this case expanded and transnationalized)' (2014:294-95). The achievements of elite players bring mana, as it were, not just to their corresponding Pacific communities but to their clubs and associated, and often multicultural, Australian fan base.

Revisiting Hokowhitu's analysis of why sport is seen as so significant:

My father, like many Māori of his generation, lived for sports. He grew up in an era when sport was one of the few spheres where tāne could achieve success and compete with Pākeha men on an 'even playing field' and, accordingly, could gain mana in the Pàkeha world. My father's enthusiasm for sport carried over to me, along with a definition of masculinity based on the noble, physically tough, staunch, and emotion-less Māori men we witnessed on the local, provincial, and national rugby fields (Hokowhitu 2004:260).

The commodification and fetishisation of Pacific bodies by diverse audiences through the sports/media complex adds another dimension to the issue. Media and the diaspora are deterritorialised spaces where 
agency, expression and meaning are constructed in articulation with the 'offline' sociopolitical context. And this offline sociopolitical context has its own particular sets of challenges and opportunities. Being a Pacific Islander in New Zealand or the United States, where there are named Pacific Islander agencies, programs and statutory bodies, is very different from being a Pacific Islander in Australia, where issues such as Pasifika education, health and welfare are dealt with, fairly inconsistently, at the state level. And within Australia, being a Pacific Islander in Canberra, with smaller, dispersed Pacific populations, is different from being a Pacific Islander in Campbelltown, Western Sydney, or Logan, Queensland, where they are concentrated and visible. While Pacific peoples across the globe celebrate their football, rugby union and rugby league stars, what that means to communities on the ground in their particular social and political circumstances varies considerably.

Location shapes how different agents participate and make meaning, and Australia is a particular kind of national, cultural, economic, political and geographic context compared with the United States, New Zealand or even Fiji as a migration destination. Expressions of difference, for example through distinct ethnic identities in Australia, do not always convert into social or cultural capital in the same way they might in other countries, including the United States where categories such as Native American, Asian American and Pacific Islander American exist and mean something structurally.

While there are still similar experiences of structural marginalisation and economic disadvantage, there is less to be gained, socially, for example, by being a Samoan or Tongan in a school in Melbourne, compared with being a Samoan or Tongan in a school in Auckland or Utah with their high, concentrated Polynesian populations. So while the strategies to integrate or assimilate into dominant cultures are strong in all of these contexts, the pressures and tactics in Australia are particular to this country's racial and indigenous politics. These are historically shaped by the protracted denial of Indigenous Australian rights; the White Australia policy focused on populating the country with white migrants from 1901 to 1973 , and a current prioritisation of 'skilled' migration. Compared with New Zealand and the United States, and in spite of relying on blackbirder labour from Melanesia on Queensland plantations from 1863 to 1904, Australia actively discouraged migration from the Pacific, including from its former colonial territories of Papua New Guinea and Nauru. Well 
aware of the inflow of Pacific migrants now via New Zealand, Australian policymakers continue to be concerned with the Trans-Tasman Agreement (see Lee 2009:7).

Given this environment and the absence of a federal portfolio for domestic Pacific issues, Pacific Islanders in Australia have to be extra proactive in carving out safe spaces where they can celebrate their cultures and pass on their languages and values to their children. Mana is easily diffused in Australia and potentially rendered irrelevant where the pressures to assimilate, for example on sporting fields from primary school to elite levels, are strong. Pacific rugby union and rugby league players, with their large Australian fan bases, could easily play as just brown bodies in a white game, grateful they or their parents made it to Australian shores, playing in Australian professional sporting codes with all of the challenges of the migration experience. But they do not always just play the game. I propose, in a preliminary way, that there is more to the agency of elite Pacific athletes than the commodity sign. When Pacific players do not just play as brown bodies, when they draw media attention to their Pacific heritage and the centrality of 'family, faith and culture' (Lakisa et al. 2014:347), the effect can be powerful.

\section{Body Pacifica and the NRL}

In January 2012, I conducted a workshop with a team of ANU Pacific Studies staff working in collaboration with the National Rugby League (NRL) education and welfare office, particularly with former star and now welfare officer Nigel Vagana. Something one of the players said to me has helped me think about players' agency and transformative potential in what is regularly viewed as a violent game that epitomises dominant notions of Australian hypermasculinity and was replete with scandals over drugs, alcohol and gender-based violence (Hutchins and Mikosza 1998).

The player told me that the Pacific players on his team would regularly get together to pray before the game and in order to do this they would have to step out of the larger group, go into their own corner and pray together before returning to finish the rest of the pre-game ritual. After a while, the team coach and management flagged this as very non teamlike behaviour and stressed that players needed to be strong and cohesive and not highlight their differences before the game. However, rather than asking the Pacific men to stop praying, they instead decided that 
if the Islanders were going to pray, everyone was going to pray. This is quite a decision in a country which is far less publicly religious than, say, the United States, but a similar thing has also happened in rugby union (see Moloney 2008).

A few years ago, sports journalist John-Paul Moloney contacted me at ANU to ask why Pacific people had to pray all the time. It was becoming quite evident within the Brumbies that their new Pacific players had very different values from the Anglo-Australian players; values that were expressed quite visibly by conducting prayers at training sessions and before games. Moloney wrote:

Faith in a football team is no new thing. But its presence within the Canberra Super 14 team is greater than ever. Its rise has corresponded with an influx into the club of Pacific Island footballers, who almost to a man believe in Christianity, which has been indigenised within Tongan, New Zealand Māori, Fijian and Samoan communities. Flyhalf Christian Lealiifano wears his faith visibly on the field, drawing a crucifix in marker pen on strapping tape around his wrist (Moloney 2008).

One of the main reasons the rugby league team decided to go with the Pacific Islanders' prayer ritual, and why teams like the Brumbies will have to get used to prayer, is because of the current demographic realities of both sporting codes. These were announced in The Sydney Morning Herald in 2006:

Forget new rules, expansion teams and codes of conduct-the biggest influence on Australia's rugby codes has been the influx of Pacific Islanders. Some even say that it's inevitable the NRL and senior rugby union will soon be dominated by players with Tongan, Samoan or Māori blood (Lane 2006).

The sheer numbers of Pacific players, 50 per cent of the whole junior game and over 20 per cent of the top tier, means that by demographics alone these players have the potential to transform the game from the inside and make some of their cultural values and practices mainstream, particularly if they resist the impetus to assimilate into dominant Australian culture (Lakisa et al. 2014; Horton and Zakus 2009; Lakisa 2011). While I agree with many of Diaz's, Tengan's and Markham's critiques in the context of the NFL in the United States, I have observed some positive and proactive efforts by Pacific rugby and especially rugby league players in Australia to infuse the game more broadly with their own values. This is also more possible in a country the size of Australia compared with that of the United States. 
While some forms of fundamentalist Christianity and homophobia, for example, are hardly mutually exclusive, between sport, popular culture and this particular Australian context, new possibilities for transforming perceptions of Pacific men and Pacific communities are possible. If (niu/new) mana is about a state of being strong, efficacious, prosperous, successful, having 'status and prestige' (Palmer and Masters 2010), and doing mighty or even miraculous acts, especially when they score tries, tackle, run fast and help win games, then I wonder if, in both senses of the word, whether noun or verb, and as 'force', players truly have the potential to increase their own and the more general mana of Pacific communities, many of whom are struggling in the Australian system. Revisiting Diaz's observations about the stakes of mana, what are the direct links between mana, masculinity and sport? Is 'new mana' dependent on a still hypermasculine 'new warrior' to reinstate authority lost in the process of colonialism and migration? Or is there another possibility within the sphere of men's sport to enhance this shared mana?

Let us take a look at three very different players who represent the most visible masculine Pacific types within the game. Someone like SamoanNew Zealander Sonny Bill Williams may not have as much potential for gaining or conferring mana as he is sometimes viewed as someone who follows the paycheck, switches back and forth between rugby league and union codes, and changes clubs at a regular rate. This is not to disconnect mana from a concept of rational economics; financial success is important to Pacific communities, as are values of stability and loyalty. But Williams' potential to be viewed as a leader, rather than just a brown body with high athletic prowess in a white game, has been undermined by a range of factors including the regular sexualisation of his image.

Tongan player William Hopoate, whose father also played league and was viewed as a 'bad boy' of the game, is practically the opposite of his dad. In spite of being one of the youngest players ever drafted into the professional tier, Hopoate gave up a AU\$1.7 million contract with the Parramatta Eels to go on a two-year mission for the Church of Jesus Christ of Latter-day Saints. His decision confounded many fans and the NRL community as it was fairly unimaginable to the general public that anyone would choose the life of a missionary over being a highly paid star athlete. To Islanders, however, one could argue his choice signalled the kind of mana seen in 'a great deed', in this case, an act of Christian faith and sacrifice. 
Retired Fijian player Petero Civoniceva, whose father also played rugby, is viewed as someone with incredible mana who is senior, humble, wellrespected and leads by example. I observed this first hand in meetings with Civoniceva, current players and other stakeholders at the NRL education and welfare office in Sydney. While his Fijian surname has never been pronounced correctly-he is called 'Sivonisiva' instead of the correct 'Thivonitheva' by his teammates, fans and sports journalistswhen Petero speaks, other players listen.

While Civoniceva is respected in the game, he has not always been respected by fans. In 2008, during a game against Parramatta, an Eels fan sitting very close to the field shouted that he was a 'fucking monkey'. The fan, who was later banned for five years from attending rugby league matches, said yes he'd called him a 'fucking monkey' but it wasn't meant to be racist (Read 2008). But racism is rampant within Australian sport and Pacific and Indigenous Australian players have long been targets of verbal abuse. After his incident, the usually quiet Civoniceva decided to speak up and gave several media interviews where he denounced racism within the sport and called for a change in attitudes through an NRL anti-racism campaign. Initially the NRL agreed, but apparently no campaign ever emerged, much to his disappointment. The Australian Football League (AFL), however, championed an anti-racism campaign inspired by their outspoken Indigenous players such as 2014 Australian of the Year Adam Goodes, and drew in sporting heroes from other codes (Australian Human Rights Commission 2013). Goodes experienced racism throughout his career and particularly towards the end. In 2015, after crowds booed an Indigenous post-goal 'war dance', he took leave and subsequently retired. This sparked a national dialogue on racism in sport which was prominent in mainstream media.

After this incident, Civoniceva and other senior Pacific players decided to get together regularly to talk about some of these problems and the group has been a catalyst for a number of new initiatives. Led by NRL education and welfare officer and former League star Nigel Vagana, they have come up with projects that are specifically designed to help players become better leaders and role models within and beyond the game.

The 2010 Body Pacifica initiative, for example, was one such project. Players used their status and popularity to promote Pacific art, culture and tangible and intangible heritage with many flow-on effects for Pacific communities in and beyond New South Wales. Produced by rugby league 
player turned curator Leo Tanoi and Carli Leimbach, Body Pacifica ran from June to August 2010 at the Casula Powerhouse Arts Centre in Liverpool, Western Sydney, and involved a diverse program of exhibitions, live performances, workshops, digital displays and sales of a very successful calendar.

The Body Pacifica calendar, which sold out in advance, was art-directed by celebrated New Zealand-born photographer of Samoan heritage Greg Semu in collaboration with graphic designer Frank Puletua, a former player and the only Pacific player with a degree in fine arts. It featured NRL players of Pacific heritage: Jarryd Hayne, Fuifui Moimoi, Paul Alton, Roy Asotasi, Dene Halatau, Frank Puletua, Nathan Cayless, Petero Civoniceva, Michael Jennings, Ruben Wiki, Manu Vatuvei, Jared WaereaHargreaves and Nigel Vagana, dressed in costumes sourced from the Pacific collection of the Australian Museum.

At the photo shoot a variety of objects was put out for them to choose from and then the photography session followed. Some players selected items that were not from their island of heritage and some players, like Jarryd Hayne (who is Fijian, born and raised in Australia), displayed the items, such as the tabua, in what most Fijians would view as an incorrect manner. A tabua or whale's tooth is not a necklace, but is something that is held and presented ceremonially.

The players' photographs were displayed in larger-than-life-dare I say god-like-images, which lined the first floor gallery of Casula Powerhouse. And like benevolent gods they seemed to watch over the three months of activities and over the many crowds that gathered during the opening and closing events. Some of them, however, did not actually show up in person; they instead lent their mana or spirit to the event and this was recognised and celebrated by the audience.

Body Pacifica was very well received by Pacific communities and the general public with Casula Powerhouse winning a NSW IMAGine award in public engagement for the exhibition. Thousands of people from the Pacific community, most of whom were not regular museum or gallery patrons, visited Casula during Body Pacifica. This helped inspire Vagana, Civoniceva and other players to take another initiative. In 2011, after almost two years of on-and-off discussions between my school's director at the time, Kent Anderson, the co-owner of the South Sydney Rabbitohs Peter Holmes à Court, and Vagana, I was asked to join the new NRL 
Pacific Council as a Pacific Studies expert to help the education and welfare office come up with ideas for new ways to enhance education, leadership and positive role modelling for Pacific players.

Kent Anderson saw this collaboration as an important opportunity for Pacific Studies to strategically expand its research, education and outreach goals. We designed a Pacific Studies leadership camp where elite players from 13 professional clubs would engage with Pacific history, religion, literature and the performing arts. They went through a series of lectures and workshops and put together final performances that reflected their learning. A team of Pacific Islander scholars and Papua New Guinean choreographer Julia Gray facilitated the three-day event with additional mentoring and inspiration from visitors to the camp such as Tofiga Fepulea 'i of the internationally acclaimed comedy duo Laughing Samoans, former NFL player Richard Brown and Australian Idol contestant and Māori pop singer Stan Walker.

At the end of the camp, the players reported that the history and leadership modules had had a significant impact on their sense of Pacific history, identity and culture and they were motivated to spread this throughout their club communities. At this point, I handed the project over to other members of the team for further collaboration but I was struck by how this very short exposure to many of the core aspects of Pacific Studies learning had a reported impact on elite athletes, most of whom-unlike their NFL counterparts who play college football and therefore study throughout a significant period of their careers-had received little higher education, technical or academic. It is well known within the NRL that Pacific Islander players do not take advantage of higher education opportunities compared with their Anglo-Australian counterparts.

While the Body Pacifica exhibition had catalysed a much needed public display of Pacific pride, the NRL education and welfare office was keen to take this further and deepen the historical and cultural knowledge of their players. In Hokowhitu's terms, they had enhanced the mana of their communities and potentially increased their own mana by gaining respect through the lending of their regularly commoditised bodies and images to celebrate Pacific culture instead. Now Vagana wanted to ensure that they did indeed have a deeper knowledge of that culture via education. 


\section{Reflection}

Migrant Pacific Islanders are transforming and applying new interpretations of both mana and tapu (taboo) in their diasporic contexts. For example, diasporic groups will apply these notions to sacred Pacific objects in museums in their new countries of residence. While they may not always understand the meaning of the objects in their original contexts, such objects have come to signify an important link to the ancestors and the Islands, bridging that distance in both time and space (Singh and Blake 2012). It is that distance from the home island context and the ways in which publicly visible bodies, acts or objects become infused with the potential mana-efficacy and image-of whole communities which requires a rethinking of the stakes of mana compared with earlier studies focused on understanding its formal linguistic properties and application in the islands.

What I have done here is lay out some questions, reflected on what others such as Tengan, Markham, Hokowhitu, Diaz and Uperesa have signalled already in their research, and presented the Australian diasporic context as offering further opportunities for critical examination of the concept or effect of mana. I do not believe the word itself needs to be present or regularly utilised in Pacific diasporic discourse for its essential qualities or effects to be relevant. As argued by Diaz, mana is still the best concept to capture what is at stake in the relationship between Pacific sporting icons and the communities they represent. The deeds, words and images of an elite Pacific athlete can uplift or shame their entire cultures. This is the nature of Pacific, and especially Polynesian, relational personhood. As writer Sia Figiel has poignantly offered in her succinct characterisation of Samoan collective identity: "“I” is “we”... always' (1996:136).

Australia is a new and certainly less understood or researched diasporic space compared with the United States and New Zealand, and one that has deeply unresolved racial politics, but it is also a kind of open field for Islanders to transform and claim in their own ways. The kind of mana created by something like Body Pacifica or the NRL leadership camp is both individual and collective, noun and verb, human and object, and also fleeting. A chief's or God's mana might need to be proven but is supposed to be durable, but an athlete's power is often short term and almost always ends in one kind of defeat or another by virtue of the fact that retirement or injury means they cannot exercise athletic prowess any more in the same way. 
Currently, while there are concentrations of Pacific communities and inspiring personalities and deeds evident within suburbs across several states, it remains to be seen what kind of niu space Australia will become for Pacific Islanders. That is, a space infused with and informed by Pacific flavours, styles and values regardless of gender, artistic talent or athletic prowess. At the moment, in spite of the seasonal explosion of male Islander bodies across the sporting fields and flat screen televisions of countless Australian homes, Pacific peoples and the Pacific Islands still occupy the edges of Australian consciousness, especially with the intense and strategic economic, educational and political turn within the last 20 years towards Asia.

\section{References}

Ansley, G. 2012. Australia’s Pacific Gangland. New Zealand Herald, 21 January. www.nzherald.co.nz/world/news/article.cfm?c_id=2\&objectid=10780126 (accessed 11 October 2015).

Australian Human Rights Commission 2013. Racism: It Stops with Me. YouTube, 23 May. www.youtube.com/watch?v=ASsZ-u9YV3c (accessed 4 April 2014).

Banivanua-Mar, T. 2007. Violence and Colonial Dialogue: The Australian-Pacific Indentured Labor Trade. Honolulu: University of Hawai'i Press.

Besnier, N. 2012. The Athlete's Body and the Global Condition: Tongan Rugby Players in Japan. American Anthropologist 39(3):491-510. doi.org/10.1111/ j.1548-1425.2012.01377.x

Betz, E. 2013. Unemployment not the cause of Pacific Islander violence in Logan. The Conversation, 18 January. theconversation.com/unemployment-not-thecause-of-pacific-islander-violence-in-logan-11650 (accessed 3 September 2014).

Boucher, D. 2012. On Finding our Own Voices: Australia's Samoan Diaspora, Representation and Identity. BA Honours thesis, Griffith University.

Cadzow, J. 2013. The Quiet One. The Sydney Morning Herald, 30 May. www. smh.com.au/rugby-league/league-news/the-quiet-one-20130422-2i948. html (accessed 9 September 2014, site discontinued).

Crocombe, R. 1976. The Pacific Way: An Emerging Identity. Suva: Lotu Pacifica.

Diaz, V. 2011. Tackling Pacific hegemonic formations on the American gridiron. Amerasia Journal37(3):90-113. doi.org/10.1111/j.1548-1425.2012.01377.x 
Figiel, S. 1996. Where We Once Belonged, Auckland: Pasifika Press.

Giggacher, J. 2014. Kindred Spirits (Interview with Margaret Jolly). Original, abridged article in the ANU Reporter, Autumn:28-29. pasifika.anu.edu.au/ news-events/all-stories/kindred-spirits (accessed 8 September 2014).

Golub, A. and J. Peterson 2016. How Mana Left the Pacific and Became a Video Game Mechanic. In M. Tomlinson and Ty P. Kāwika Tengan (eds), New Mana: Transformations of a Classic Concept in Pacific Languages and Cultures. Canberra: ANU Press. doi.org/10.22459/NM.04.2016.12

Hill, B. 2013. Maori/Pacific Gang Violence in Australia. Radio Australia, 15 May. www.radioaustralia.net.au/international/radio/program/pacific-beat/maori pacific-gang-violence-in-melbourne/1131308 (accessed 12 October 2015, site discontinued).

Hokowhitu, B. 2004. Tackling Māori Masculinity. The Contemporary Pacific 16(2):259-84. doi.org/10.1353/cp.2004.0046

Horton, P. and D. Zakus 2009. Pacifica in Australian Rugby: Emanant (sic) Social, Cultural and Economic Issues. Sporting Traditions 26(2):67-86.

Hutchins, B. and J. Mikosza 1998. Australian Rugby League and Violence 19701995: A Case Study in the Maintenance of Masculine Hegemony. Journal of Sociology 34:246-63. doi.org/10.1177/144078339803400303

IFWT Productions and ITVS 2014. In Football We Trust (documentary film). Trailer online: www.youtube.com/watch?v=0I6vb4XwV0o (accessed 9 October 2015, site discontinued).

Keesing, R.M. 1984. Rethinking 'mana'. Journal of Anthropological Research 40(1):137-56. doi.org/10.1177/144078339803400303

Kolshus, T. 2016. Mana on the Move: Why Empirical Anchorage Trumps Philosophical Drift. In M. Tomlinson and Ty P. Kāwika Tengan (eds), New Mana: Transformations of a Classic Concept in Pacific Languages and Cultures. Canberra: ANU Press. doi.org/10.22459/NM.04.2016.06

Lakisa, D. 2011. The Pacific Revolution: Pacific \& Māori Players in Australian Rugby League. MA thesis, Southern Cross University, New South Wales.

Lakisa, D., D. Adair and T. Taylor 2014. Pasifika Diaspora and the Changing Face of Australian Rugby League. The Contemporary Pacific 26(2):347-67. doi.org/10.1353/cp.2014.0029 
Lane, D. 2006. Islanders in Junior Leagues, it's a Really Big Issue. The Sydney Morning Herald, 16 July. www.smh.com.au/news/league/islanders-in-juniorleagues-its-a-really-big-issue/2006/07/15/1152637922188.html (accessed 12 October 2015).

Lawson, S. 2010. 'The Pacific Way' as Postcolonial Discourse: Towards a Reassessment. Journal of Pacific History 45(3):297-314. doi.org/10.1080/ 00223344.2010 .530810

Lee, H. 2009. Pacific Migration and Transnationalism: Historical Perspectives. In H. Lee and S.T. Francis (eds), Migration and Transnationalism: Pacific Perspectives. Canberra: ANU E Press, 7-42. doi.org/10.22459/MT.08. 2009.01

Lee, H. and S.T. Francis (eds) 2009. Migration and Transnationalism: Pacific Perspectives. Canberra: ANU E Press. doi.org/10.22459/MT.08.2009

Lewis-Harris, J. 2011. Dancing on the Weekend: Papua New Guinea Culture Schools in Urban Australia. Intersections: Gender and Sexuality in Asia and the Pacific 27 (November). intersections.anu.edu.au/issue27/lewis-harris.htm (accessed 2 September 2014).

Lilley, C. 2014. Jonah from Tonga (television series). Melbourne: Princess Pictures.

Madang Wansolwara Dance 2014. Papua New Guinea Mine Watch blog. ramumine.wordpress.com/2014/09/01/madang-wansolwara-dance/ (accessed 3 September 2014).

Mallon, S. and P.F. Pereira (eds) 2002. Pacific Art Niu Sila: The Pacific Dimension of Contemporary Arts in New Zealand. Wellington: Te Papa Press.

Massoud, J. 2013. Reni Maitua Has Revealed how He Hit Rock Bottom and Attempted to Take His Own Life. The Sunday Telegraph, 14 December. www. foxsports.com.au/nrl/nrl-premiership/reni-maitua-has-revealed-how-he-hitrock-bottom-and-attempted-to-take-his-own-life/news-story/1c4068cf0957 0e0f574e8fb81a8e6fcf? (accessed 9 September 2014).

Moloney, J.P. 2008. New Brumbies Profess the Faith. The Canberra Times, 17 December. www.smh.com.au/rugby-union/union-news/new-brumbiesprofess-the-faith-20091124-j902.html\#ixzz3CDkMEuI3 (accessed 2 September 2014, site discontinued).

Morgain, R. 2016. Mana for a New Age. In M. Tomlinson and Ty P. Kāwika Tengan (eds), New Mana: Transformations of a Classic Concept in Pacific Languages and Cultures. Canberra: ANU Press. doi.org/10.22459/NM.04.2016.11

Palmer, F. and T. Masters 2010. Māori Feminism and Sport Leadership. Sport Management Review 13(4):331-44. doi.org/10.1016/j.smr.2010.06.001 
Pryke, J. 2014. Pacific Islanders in Australia: Where are the Melanesians? DevPolicyBlog, 28 August. www.devpolicy.org/pacific-islanders-in-australiawhere-are-the-melanesians-20140828/ (accessed 2 September 2014).

Pryor, N. 2013. Maori in Oz: Living the Good Life. Stuff, 19 July. www.stuff.co.nz/ national/8937746/Maori-in-Oz-Living-the-good-life (accessed 12 October 2015).

Queensland Health 2013. Pacific Islander and Maori Population Size and Distribution. www.health.qld.gov.au/multicultural/health_workers/pac-islandpop (accessed 11 October 2015).

Read, B. 2008. Petero Civoniceva Racial Abuser Banned from League Games. The Australian, 9 July. www.theaustralian.com.au/archive/news/civoniceva-racialabuser-banned-by-nrl/story-e6frg7mo-1111116859701?nk=c707862ddd0d 4ad38c5ee30ad197f35b (accessed 3 September 2014, site discontinued).

Rose, S., M. Quanchi and C. Moore 2009. A National Strategy for the Study of the Pacific. Brisbane: Australian Association for the Advancement of Pacific Studies.

SBS 2014. Chris Lilley Facing Social Media Backlash over 'Racist' Jonah from Tonga, 15 May. www.sbs.com.au/news/article/2014/05/15/chris-lilley-facingsocial-media-backlash-over-racist-jonah-tonga (accessed 3 September 2014, site discontinued).

Singh, S. and M. Blake 2012. The Digitization of Pacific Cultural Collections: Consulting with Diasporic Pacific Communities and Experts. Curator: The Museum Journal 55(1): 95-105. doi.org/10.1111/j.2151-6952.2011.00132.x

Steeg, J.L. 2012. Junior Seau: Song of Sorrow. The San Diego Union-Tribune. www.utsandiego.com/news/2012/Oct/14/junior-seau-real-story/ (accessed 2 April 2014, site discontinued).

Teaiwa, K. 2007. Aussie Islanders Fight Ignorance. The Fiji Times, 30 October (original article in The Canberra Times, 29 October 2007). www.fijitimes. com/story.aspx?id=73247 (accessed 3 September 2014, site discontinued).

Teaiwa, T. and S. Mallon 2005. Ambivalent Kinships: Pacific People in New Zealand. In J.H. Liu, T. McCreanor and T. McIntosh (eds), New Zealand Identities: Departures and Destinations. Wellington: Victoria University Press, 207-29.

Tengan, T.P. Kāwika and J. Markham 2009. Performing Polynesian Masculinities in American Football: From 'Rainbows to Warriors'. International Journal of the History of Sport 26(16):2412-31. 
Tomlinson, M. 2006. Retheorizing Mana: Bible Translation and Discourse of Loss in Fiji. Oceania 76(2):173-85. doi.org/10.1002/j.1834-4461.2006. tb03043.x

Tomlinson M. and S. Bigitbau 2016. Theologies of Mana and Sau in Fiji. In M. Tomlinson and Ty P. Kāwika Tengan (eds), New Mana: Transformations of a Classic Concept in Pacific Languages and Cultures. Canberra: ANU Press. doi.org/10.22459/NM.04.2016.09

Uperesa, F.L. 2014. Fabled Futures: Migration and Mobility for Samoans in American Football. The Contemporary Pacific 26(2): 281-301. doi.org/ $10.1353 /$ cp.2014.0045

Vasta, E. 2004. Community, the State and the Deserving Citizen: Pacific Islanders in Australia. Journal of Ethnic and Migration Studies 30(1):195-213. doi.org/10.1080/1369183032000170231

Winitana, M. 2008. Contemporary Conceptions of Mana Wahine Māori in Australia: A Diasporic Discussion. Mai Review 3, Research Note 4:1-8. 
This text is taken from Understanding Oceania: Celebrating the University of the South Pacific and its collaboration with The Australian National University, edited by Stewart Firth and Vijay Naidu, published 2019 by ANU Press, The Australian National University, Canberra, Australia.

doi.org/10.22459/UO.2019.18 